\title{
Hubungan tekanan intraocular dengan diabetes retinopati proliferatif
}

\author{
${ }^{1}$ Felix Martua \\ ${ }^{2}$ Laya Rares \\ ${ }^{2}$ Yamin Tongku
}

\author{
${ }^{1}$ Kandidat Skripsi Fakultas Kedokteran Universitas Sam Ratulangi Manado \\ ${ }^{2}$ Bagian Ilmu Kesehatan Mata Fakultas Kedokteran Universitas Sam Ratulangi Manado \\ Universitas Sam Ratulangi Manado \\ Email: hutagalungfelix@yahoo.co.id
}

\begin{abstract}
Abstrak: Diabetes Mellitus (DM) adalah penyakit tidak menular yang diderita lebih dari 170 juta orang di seluruh dunia, salah satu komplikasi dari DM adalah diabetes retinopati dimana salah satu bentuknya adalah proliferatif (PDR). Jika PDR tidak ditangani dengan cepat maka akan menimbulkan penurunan tajam penglihatan dan disertai peningkatan tekanan intraokular (TIO). Penelitian ini dilakukan untuk menemukan hubungan antara PDR dengan peningkatan TIO. Penelitian dilakukan dengan metode analitik retrospektif, dengan menggunakan data rekam medik dari pasien yang berobat di Poliklinik Mata RSUP Prof. R.D. Kandou Manado periode Januari 2015-September 2016. Data yang diambil antara lain status tekanan intraocular dan tanda vital pasien sebelum menerima tindakan terapi. Dari 24 data rekam medik pasien yang memenuhi kriteria didapat 15 pasien jenis kelamin perempuan $(62,5 \%)$ dan 9 pasien jenis kelamin laki-laki $(37,5 \%)$. Rentang usia paling banyak terkena PDR adalah 55-64 tahun sebanyak 10 orang $(41,7 \%)$. Hasil analisis menggunakan metode analisis regresi dengan variabel dummy terdapat tingkat hubungan sebesar $29,7 \%$ yang berarti PDR sedikit berpengaruh pada TIO, dengan $\mathrm{p}=0,03$ yang menunjukkan hubungan yang kurang signifikan antara PDR dan TIO $(p<0,05)$. Simpulan: didapat hubungan yang kurang signifikan antara PDR dan TIO.
\end{abstract}

Kata kunci: diabetes retinopati proliferatif, tekanan intraokular

\begin{abstract}
Diabetes Mellitus (DM) is an uninfectious disease that affect more than 170 million persons worldwide. Diabetic retinopathy is one of the most common complication on people with diabetes, and Proliferative Diabetic Retinopathy (PDR) is the most severe form of diabetic retinopathy. PDR will cause vision loss if not treated quickly and causing elevation of intraocular pressure (IOP). PDR and its association with elevation of IOP is the main focus of this study. This study was an analytic-retrospective, using the data from medical record of patients that visits Polyclinic of Opthalmology in Prof. R.D. Kandou Hospital from January 2015 until September 2016 period. Data used for this study is IOP, vision status, and vital sign, and the IOP was measured before patient taking any medication. From 24 samples were used for this study, 15 of them is females $(62,5 \%)$, based on age span, most patients with PDR are between 55-64 y.o. by 10 people $(41,7 \%)$. Analytic result using dummy variable shows PDR has little effect to IOP, by $29,7 \%$ and shows little signifancy $(p=0,03 ; p<0,05)$. Conclusion: PDR has little significant correlation to IOP.
\end{abstract}

Keywords: proliferative diabetic retinopathy, intraocular pressure

Diabetes Mellitus (DM) adalah penyakit tidak menular yang diderita lebih dari 170 juta orang di seluruh dunia dan diperkirakan akan mencapai 366 juta di tahun 2030. Data dari Riset Kesehatan Dasar (Riskesdas) menunjukkan bahwa 
terdapat 40.772 penduduk provinsi Sulawesi Utara diatas 15 tahun menderita diabetes, ${ }^{1}$ jumlah ini cukup merisaukan karena $75 \%$ dari mereka yang sudah menderita diabetes lebih dari 20 tahun kemungkinan akan terkena diabetes retinopati. $^{2}$

WHO memperkirakan jumlah kebutaan akibat diabetes retinopati sebesar $4,8 \%$ dari semua kasus kebutaan di seluruh dunia. Sekitar $42 \%$ penyandang diabetes di Indonesia menderita komplikasi retinopati dimana $6,4 \%$ diantaranya adalah Proliferative Diabetic Retinopathy (PDR). ${ }^{3}$

Tekanan Intraokular (TIO) adalah tekanan yang dihasilkan oleh cairan dalam bola mata, kisaran normalnya adalah 10-21 mmHg. Jika tekanan melebihi batas normal maka akan menimbulkan masalah pada mata seperti penyempitan lapang pandang, hingga penurunan

Tajam penglihatan akibat tekanan pada saraf optik. ${ }^{4}$

Beberapa studi menunjukkan adanya kaitan antara retinopati diabetic dengan peningkatan tekanan intraokular. ${ }^{5-8}$ Hal-hal diatas melatar belakangi ketertarikan peneliti untuk mengamati hubungan PDR dengan peningkatan TIO.

\section{METODE PENELITIAN}

Penelitian bersifat analitik retrospektif dengan menggunakan data rekam medik pasien PDR yang berobat di Poliklinik Ilmu Kesehatan Mata RSUP Prof. R.D. Kandou Manado periode Januari 2015September 2016. Data yang diambil antara lain TIO dan status vital pasien. TIO diukur menggunakan tonometry Schiotz dan hasil diambil sebelum pasien menerima tindakan medis apapun yang dapat mempengaruhi tekanan TIO.

Jumlah keseluruhan sampel sebanyak 24 orang. Analisis hubungan dilakukan menggunakan program SPSS, dimana metodeanalisis yang digunakan adalah regresivariabel dummy.

\section{HASIL PENELITIAN}

Distribusi sampel menurut umur dibagi berdasarkan pembagian yang digunakan
Riskesdas yang dapat dilihat pada Tabel 1

Tabel 1. Distribusi sampel menurut umur

\begin{tabular}{lcc}
\hline Umur & $\mathrm{n}$ & $\%$ \\
\hline $25-34$ & 1 & 4,2 \\
$35-44$ & 2 & 8,3 \\
$45-54$ & 7 & 29,2 \\
$55-64$ & 10 & 41,7 \\
$65-74$ & 3 & 12,5 \\
$>75$ & 1 & 4,2 \\
Jumlah & 24 & 100 \\
\hline
\end{tabular}

Tabel 2. Distribusi sampel menurut jenis kelamin

\begin{tabular}{lcc}
\hline Jenis Kelamin & n & \% \\
\hline Perempuan & 15 & 62,5 \\
Laki-laki & 9 & 37,5 \\
Jumlah & 24 & 100 \\
\hline
\end{tabular}

Tabel 3.Distribusi Tekanan Intraokular

\begin{tabular}{ll}
\hline Subjek & $\begin{array}{l}\text { TIO }(\mathrm{mmHg}) \\
\text { Mean }+\mathrm{SD}^{*}\end{array}$ \\
\hline Semua & $15.8+2.7$ \\
Laki-laki & $12.8+3.1$ \\
Perempuan & $17.5+3.7$ \\
\hline
\end{tabular}

$* \mathrm{SD}=$ Standard Deviation

Hasil analisis dengan menggunakan metode regresi variabel dummy menunjukkan hubungan antara PDR dengan TIO sebesar 29,7\%, sementara signifikansi (Sig.) $p=0,03$

\section{BAHASAN}

Berdasarkan hasil penelitian, sampel terbanyak adalah jenis kelamin perempuan, hal ini mendekat ipenelitian yang dilakukan Davis et al bahwa perempuan adalah salah satu factor resiko minor dari PDR. ${ }^{9}$

Hasil analisis variabel dummy menunjukkan hubungan yang kurang signifikan antara PDR dengan TIO $(29,7 \%)$, dan diperkuat dengan hasil ANOVA $p=0,03(\mathrm{p}<0,05)$.

Kondisi pembuluh darah retina yang iskemik akibat diabetes memicu ekspresi VEGF (Vascular Endothelial Growth Factor) oleh mikroglia, yang meningkat 
pada kondisi hipoksia. ${ }^{10}$ VEGF memicu neovaskularisasi di retina sehingga terbentuk pembuluh darah baru yang memiliki beberapa kelemahan pada membrane basalis, lapisan endotel, dan ikatan intraselulernya sehingga pembuluh darah itu akan rusak dan menyebabkan kebocoran protein dan perdarahan retina (vitreous hemorrhage). ${ }^{11}$ Tingkat ekspresi VEGF dipengaruhi oleh hypoxia-inducible factor 1 (HIF-1 $\alpha)$ yang ditemukan meningkat pada sel ganglion setelah peningkatan TIO. ${ }^{12}$

\section{SIMPULAN DAN SARAN}

Dari hasil penellitan yang telah dijabarkan, maka dapat ditarik kesimpulan sebagai berikut:

1. Didapat hubungan kurang signifikan antara PDR dan TIO $(\mathrm{p}=0,03)$

2. Didapat peningkatan TIO pada sampel secara keseluruhan sebesar 14,6\% , sampel laki-laki sebesar $19.5 \%$, dan sampel perempuan sebesar $17,5 \%$.

3. Dari 24 sampel, sebagian besar sampel adalah jenis kelamin perempuan 15 orang.

Penelitian yang dilakukan masih memiliki banyak kelemahan, seperti jumlah sampel yang kurang memadai sehingga hasil akhir yang didapat kurang memuaskan, juga data dari rekam medik yang masih perlu untuk dilengkapi kedepannya, sehingga diharapkan bagi para tenaga medis untuk melakukan pencatatan rekam medik yang lebih lengkap untuk mempermudah berbagai keperluan nantinya.

\section{DAFTARPUSTAKA}

1. Kementrian Kesehatan RI-Pusat Data dan Informasi (Infodatin) Diabetes2014. h.4 available from http://www.depkes.go.id/resources/ download/pusdatin/infodatin/infodat in-diabetes.pdf

2. World Health Organization- Prevention of
Blindness from Diabetes Mellitus. WHO Library Cataloguing-inPublication Data. 2005. h.7

3. Sitompul R. Retinopati Diabetik J Indon Med Assoc 2011;61:1-5

4. Ilyas HS. Ilmu Penyakit Mata. Edisi Ke-5. Jakarta ; FKUI; 2015 h.222-34

5. Mitchell P, Smith W, Chey T, Healey PR, Open-angle Glaucoma and diabetes: the Blue Mountains Eye Study Australia. Opthalmol 1997;104;712-718

6. Bonovas S, Peponis V, Filioussi $K$. Diabetes mellitus as a risk factor for primary open-angle glaucoma: a meta-analysis, Diabetic Medicine, 21, 609-614

7. Klein B., Klein R., Jensen S. Open-angle glaucoma and older onset diabetes. The Beaver Dam Eye Study. Opthalmol1994; 101; 1173-77

8. Tielsch JM, Katz J, Quigley HA, Javitt JC, Sommer A. Diabetes, intraocular pressure, and primary open-angle glaucoma in the Baltimore Eye Survey. Ophthalmol 1995; 102; 48-53

9. Davis MD, Fisher MR, Gangnon RE, Barton F, Aiello LM, Chew EY et al. Risk Factors for High-Risk Proliferative Diabetic Retinopathy and Severe Visual Loss: Early Treatment DiabeticRetinopathy Study Report \#18. Invest Ophthalmol Vis Sci. 1998;39:233252

10. D'amore P., Saint-Geniez $M$. Development and pathology of the hyaloid, choroidal and retinal vasculature. Int.J.Dev.Biol. Boston 2004; 48; 1045-1058

11. Nentwich $M$, Ulbig $M$. Diabetic Retinopathy- ocular complications of diabetes mellitus. World $J$ Diabetes 2015; 6(3): 489-499

12. Wong V., Bui B., Vingrys A. Clinical and Experimental Links Between Diabetes and Glaucoma. ClinExpOptom 2011; 94; 1; 4-23 